H A R VAR D

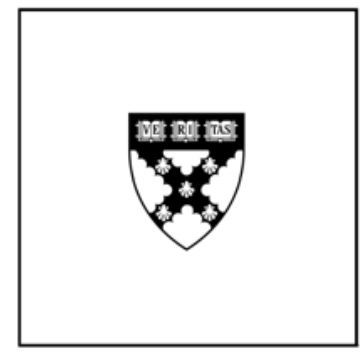

\title{
Gray Markets and Multinational Transfer Pricing
}

Romana Autrey

Francesco Bova

\section{Working Paper}

09-098 


\title{
GRAY MARKETS AND MULTINATIONAL TRANSFER PRICING
}

\author{
Romana Autrey* \\ Harvard Business School \\ Francesco Bova \\ Rotman School of Management \\ University of Toronto \\ October $7^{\text {th }}, 2009$
}

Gray markets arise when a manufacturer's products are sold outside of its authorized channels, for instance when goods designated for a foreign market are resold domestically. One method multinationals use to combat gray markets is to increase internal transfer prices to foreign subsidiaries in order to increase the gray market's cost base. We illustrate that, when a gray market competitor is present, the optimal price for internal transfers not only exceeds marginal cost, but is also a function of the competitiveness of the upstream economy. Moreover, the presence of a gray market competitor may cause unintended social welfare consequences when domestic governments mandate the use of arm's length transfer prices between international subsidiaries. When markets are sealed, arm's length transfer pricing strictly increases domestic social welfare. In contrast, we demonstrate that when a gray market competitor is present, mandating the use of arm's length transfer pricing decreases domestic social welfare when the domestic market is sufficiently large relative to the foreign market. Specifically, a shift to arm's length transfer pricing erodes domestic consumer surplus by making the gray market less competitive domestically, which in turn may offset any domestic welfare gains that accompany a shift to arm's length transfer pricing. Finally, the analysis illustrates that in a gray market setting, the transfer price that maximizes a multinational's profits may also be the same one that maximizes the social welfare of the domestic economy that houses it.

Keywords: transfer pricing, gray markets, regulation

JEL Classification: M41; D43; F23

*Corresponding author: rautrey@hbs.edu

We thank Pingyang Gao, Brian Mittendorf, V.G. Narayanan, Paul Newman, Gord Richardson and seminar participants at the 2009 AAA Annual Meeting, the 2009 ARW Conference, and the University of Toronto for suggestions and helpful comments. We also thank Dae-Hee Yoon for his thoughtful and detailed comments. All errors are our own. 


\section{Introduction}

Gray market goods are brand name products that are initially sold into a designated market but then resold through unofficial channels into a different market. This paper considers goods originally sold in a foreign market and then reimported domestically through channels unauthorized by the trademark owner. Gray markets can arise when transaction and search costs are low enough to allow products to "leak" from one market segment back into another. Examples of industries with active gray markets include pharmaceuticals, automobiles, and electronics. Understandably, reactions to gray market encroachment are mixed.

On the one hand, consumer advocates and governments have applauded the increasing role that gray markets have played in improving competition for domestic goods. This sentiment has been supported in the U.S. by court rulings that have left copyright holders with little means of enforcing contracts prohibiting the unauthorized importation of goods from foreign countries. ${ }^{1}$ Moreover, several international regulatory authorities have gone so far as to take proactive stances to curbing firms' efforts to negate gray markets. For example, the European Commission recently sent a statement of objection to Apple Inc. for restricting its customers to buying products solely from online stores in their own country - a practice which effectively eliminates gray market activity. $^{2}$

On the other hand, multinationals have decried the increasing role of gray markets in the economy, with an estimated $\$ 40$ billion in cannibalized sales resulting from gray markets in the information technology sector alone (estimate by the Alliance for Gray Market and Counterfeit Abatement; see www.agmaglobal.org). Additionally, theory and evidence (see for example, Li and Robles (2007)) suggest that gray markets may stifle the incentive to innovate, as gray markets prevent firms from reaping the full rewards of their research and development.

\footnotetext{
${ }^{1}$ Quality King Distributors Inc., v. L'anza Research International Inc., 523 U.S. 135 (1998)

${ }^{2}$ http://news.bbc.co.uk/2/hi/business/6520677.stm, accessed 31 January 2009.
} 
Anecdotal evidence in Assmus and Weise (1995) and Antia et al. (2004) suggests several methods that multinationals might use to combat gray markets. The methods can be loosely categorized as either preventing gray market activity or punishing gray market activity. Examples of actions taken to prevent gray market activity include differentiating products across regions and reducing arbitrage opportunities (such as modifying transfer prices or retail prices). Examples of punishing gray market activity include fines, legal action, and withholding reward programs (such as manufacturer rebates or access to the newest products). However, as punishing gray market activity requires that the multinational be able to identify the elusive responsible party - an expensive and extremely time-consuming task - many firms employ prevention methods as their primary defense against gray market activity.

In choosing among the various methods of prevention, multinationals are often reluctant to specify worldwide retail prices because doing so sacrifices the fundamental benefits of pricing for local markets: specifically, setting prices to accommodate local demand and the ability to act swiftly to local changes in competition and preferences (Assmus and Weise (1995), Antia et al. (2004)). Accordingly, this paper focuses on the inflation of internal transfer prices to foreign subsidiaries as a mechanism to combat gray market activity. The intuition behind the strategy is straightforward. Higher transfer prices increase the foreign arm's cost base which leads to higher end-user prices in the foreign market and a higher cost base for the gray market. The higher the gray market's cost base, the less competitive it is when it reimports product back into the domestic market, and the fewer the sales it cannibalizes from the domestic parent.

The findings in Assmus and Weise (1995) imply that gray market activity may influence the optimal price for internal transfers between a multinational's affiliated segments. There is an extensive literature which assesses optimal transfer pricing between related parties, starting with the seminal work of Hirshleifer (1956). The findings in Hirshleifer (1956) are particularly applicable to the gray market setting. Hirshleifer (1956) finds that if an affiliated downstream division is a price setter, and upstream and downstream markets are sealed from one another, then the optimal price for internal transfers is the marginal cost of the upstream division. However, if there is 
product leakage from the downstream market to the upstream one, then the optimal transfer price falls between the transferred product's marginal cost and its market price.

Consistent with Hirshleifer (1956) and anecdotal evidence in Assmus and Weise (1995), we find that the optimal price of a multinational's internal transfers is the transferred product's marginal cost when international market segments are sealed from one another. However, when a gray market "leaks" product from a foreign market to a domestic one, the optimal transfer price falls between marginal cost and the arm's length price. $^{3}$ We provide an extension to Hirshleifer's results by also defining the optimal transfer price as a function of both the level of differentiation between the foreign and domestic product and the number of competitors in the domestic market. Additionally, while Hirshleifer illustrates that the optimal transfer price between affiliated segments is a function of the nature of downstream competition, we illustrate that, conditional on there being product leakage from the downstream to the upstream market, the optimal transfer price is additionally a function of the nature of upstream competition.

While the results suggest several new determinants to explain variation in intracompany discounts across multinationals, we note that a multinational's discretion to set internal transfer prices is typically restricted by the domestic government that regulates it. In the case of the U.S., multinationals must set transfer prices to foreign subsidiaries at arm's length via one of several prescribed methods. One presumed benefit to imposing the arm's length standard is that doing so should maximize domestic social welfare, by maximizing the profits repatriated domestically from a foreign market.

Consistent with this intuition, we find that a shift from the multinational's profit maximizing transfer price to an arm's length transfer price leads to strict increases in domestic social welfare when the foreign and domestic markets are sealed from one another. However, we find unintended social welfare consequences from a similar shift to arm's length transfer pricing when a gray market firm leaks product from a foreign market to a domestic one. Specifically, shifting to the arm's length standard erodes

\footnotetext{
${ }^{3}$ This result also adds to the literature that finds benefits to pricing internal transfers above marginal cost despite potential decreases in channel efficiency (see, Arya and Mittendorf (2007), Arya and Mittendorf (2008) and Arya et al. (2008)).
} 
consumer surplus in the domestic market by making the gray market a comparatively high cost producer and, in turn, less competitive domestically. We characterize the circumstances under which the welfare destruction arising from this erosion dominates the welfare gains which arise from the increase in repatriated foreign profits to the multinational's domestic arm. Finally, and perhaps surprisingly, we find that in a gray market setting, the transfer price that maximizes a multinational's profits may also be the same one that maximizes the social welfare of the domestic economy that houses it.

This study's principal contribution is to challenge the notion that allowing multinationals the discretion to set their own internal transfer prices leads to benefits which help only the multinational. In this respect, the results echo those in Smith (2002). Smith (2002) finds that allowing firms the ex post discretion to set transfer prices can lead to favorable ex ante resource allocation and efficiency gains that potentially offset any reduction in tax receipts. In a similar vein, we find that allowing firms to act opportunistically when gray markets encroach may lead to increases in consumer surplus that exceed any decreases to social welfare that arise by not following the arm's length standard, especially when the domestic market is large relative to the foreign market. Finally, this study provides several avenues for tax regulators to more effectively allocate resources for enforcement, as well as an analytic underpinning that helps explain variations in intracompany discounts across multinationals and the perceived lax attitude of enforcement officials when imposing the arm's length standard.

The paper proceeds as follows. Section 2 lays out the basic model. Section 3 presents the analysis and discusses the results. Section 4 concludes.

\section{Model Setup}

Consider a multinational firm that manufactures a product domestically and distributes it both domestically and in a foreign country. Domestically, the multinational sells its product through a wholly owned subsidiary (denoted firm 0 ) which competes against $n$ domestic competitors $(n \geq 0){ }^{4} \quad$ Each domestic competitor produces a

\footnotetext{
${ }^{4}$ When $n=0$, the domestic firm is a monopolist.
} 
differentiated substitute of firm 0's product. The quantity of firm i's product sold in the domestic market, $D$, is denoted $q_{i}^{D}, i=0, \ldots, n$. Demand from domestic consumers for firm i's product is represented by a linear downward sloping demand curve where $P_{i}^{D}=\alpha_{D}-q_{i}^{D}-\sum_{j \neq i} \gamma q_{j}^{D} \cdot{ }^{5} P_{i}^{D}$ is the retail price of firm i's product in the domestic market, and $\gamma \in(0,1]$ is the degree of product differentiation in the domestic market; when $\gamma=1$, all products sold in the domestic market are perfect substitutes. ${ }^{6}$ For greater tractability, we normalize the marginal cost of each firm's product to 0 .

Additionally, the multinational sells its product in a foreign market (denoted with an $F$ superscript) via a profit maximizing, related foreign subsidiary (denoted firm 0 in the foreign market). For simplicity, we assume that the foreign subsidiary has a monopoly in its respective market. The foreign subsidiary sells quantity $q_{0}^{F}$ and faces a downward sloping demand curve where $P_{0}^{F}=\alpha_{F}-q_{0}^{F}$. The multinational's central planner maximizes the multinational's profits by setting the price for internal transfers from the domestic arm to the foreign subsidiary of $p$ per unit. ${ }^{7}$ By setting a transfer price of $p$, the multinational repatriates profits of $p q_{0}^{F}$ from the foreign subsidiary to the domestic subsidiary.

\footnotetext{
${ }^{5}$ This functional form enables us to assess the impact of upstream competition on the optimal transfer price between affiliated segments.

${ }^{6}$ Often, insights derived under Cournot quantity competition are reversed under Bertrand price competition (e.g., see Bulow et al. (1985), Göx (2000)), making it important to check robustness under price competition. This is particularly important in our setting because the nature of the competition is a predominant feature (i.e., we have $n$ domestic competitors). When we recast the model as Bertrand competition, the paper's inferences are unchanged provided $\gamma$ is not too large (i.e., $\gamma<\sim .95$ ).

${ }^{7}$ Although in certain jurisdictions multinational firms are allowed to decouple their transfer price for internal and tax purposes (see Baldenius et al. (2004), Johnson (2006)), we use a single transfer price as management's decision variable. In the past, there has been mixed evidence on the use of decoupled transfer prices (e.g., see Ernst and Young (1999), Halperin and Srinidhi (1991)). However, recent empirical evidence suggests that over $80 \%$ of multinationals use a single set of transfer prices for management and tax purposes (Ernst and Young (2003), p.17). Respondents in Ernst and Young (2003) suggest that a single set of transfer prices can "enhance the defensibility of transfer prices, ease administrative burden, and add to the effectiveness of a transfer pricing program.” Additionally, while Bernard et al. (2005) hypothesize the use of decoupled transfer prices in their model, their empirical results are consistent with a single set of transfer prices.
} 
Finally, we assume that there are no differences in corporate tax rates between the domestic and foreign country. While variation in tax rates across countries may lead to variation in internal transfer prices across multinationals, there is already a robust literature that assesses the impact of tax differences on transfer pricing in a multinational setting. ${ }^{8}$ As the scope of this paper is to assess the impact that gray markets have on internal transfer prices, we exogenously hold taxes constant and equal across markets.

\section{Analysis and Discussion}

In this section, we begin by deriving the optimal transfer pricing policy under two scenarios: sealed markets (no leakage across markets, as a benchmark scenario) and gray markets (when a gray market firm reimports goods from the foreign market back to the domestic one). Next, we derive the arm's length transfer price under each scenario and compare these transfer prices to the firm's optimal transfer prices. Additionally, we assess the domestic social welfare implications of mandating arm's length transfer prices. Finally, for robustness, we characterize when the multinational firm enters the foreign market, despite supplying the gray market and thereby reducing profits in the domestic market.

\subsection{Quantity Competition with Sealed Market Segments}

We begin by deriving the optimal transfer pricing policy in an economy with sealed market segments. We solve the model by backward induction. Given a transfer price, $p$, the domestic and foreign subsidiaries choose $q_{0}^{D}$ and $q_{0}^{F}$ to maximize profits of $\pi_{0}^{D}$ and $\pi_{0}^{F}$, respectively. We assume end user quantities and prices are strictly positive and transfer prices are weakly positive. The timeline is shown in Figure 1.

\footnotetext{
${ }^{8}$ There is a substantial literature that assesses the impact of differences in tax jurisdictions on the price of internal transfers. For example, see Copithorne (1971), Horst (1971), Samuelson (1982), Halperin and Srinidhi (1987), Harris and Sansing (1998), Sansing (1999), Narayanan and Smith (2000) and Smith (2002).
} 
The multinational chooses the foreign transfer price, $p$.
Quantities are simultaneously chosen by the foreign subsidiary in the foreign market and by the domestic subsidiary and competitors in the domestic market.
Consumers make their purchases and firm profits are realized.

Figure 1: Timeline in a Sealed Market Setting

The foreign subsidiary, firm 0 in the foreign market, chooses $q_{0}^{F}$ to maximize profit:

$$
\underset{q_{0}^{F}>0}{\operatorname{Max}} \pi_{0}^{F}=q_{0}^{F}\left[\alpha_{F}-q_{0}^{F}\right]-p q_{0}^{F}
$$

The domestic subsidiary, firm 0 in the domestic market, chooses $q_{0}^{D}$ to maximize profit:

$$
\underset{q_{0}^{D}>0}{\operatorname{Max}} \pi_{0}^{D}=q_{0}^{D}\left[\alpha_{D}-q_{0}^{D}-\sum_{j \neq 0} \gamma q_{j}^{D}\right]+p q_{0}^{F}
$$

The $n$ domestic competitors each choose $q_{i}^{D}, i \neq 0$, to maximize their profits:

$$
\underset{q_{i}^{D}>0}{\operatorname{Max}} \pi_{i}^{D}=q_{i}^{D}\left[\alpha_{D}-q_{i}^{D}-\sum_{j \neq i} \gamma q_{j}^{D}\right], i \neq 0
$$

Solving the first order conditions from (1), (2) and (3) yields the equilibrium quantities $q_{0}^{F}(p)$ and $q_{i}^{D}, i=0 \ldots n$. Given these quantities, the multinational sets its internal transfer price to maximize overall profit.

$$
\underset{p \geq 0}{\operatorname{Max}}=\pi_{0}^{D}(p)+\pi_{0}^{F}(p)
$$

Solving the first order condition from (4) yields the optimal transfer price, $p^{D}$. Using the equilibrium quantities chosen by the firm's subsidiaries and competitors in response to the internal transfer price selected by the multinational's headquarters and simplifying (1), (2) and (3) yields equilibrium profits, as summarized in Lemma 1. 
Lemma 1. When markets are sealed, the equilibrium outcomes are as follows:

1. The optimal internal transfer price to the foreign subsidiary is $p^{D}=0$.

2. The equilibrium quantities chosen by the foreign subsidiary, the domestic subsidiary, and the domestic competitors, respectively, are

$$
q_{0}^{F}=\frac{\alpha_{F}}{2}, q_{0}^{D}=\frac{\alpha_{D}}{2+\gamma n} \text {, and } q_{i}^{D}=\frac{\alpha_{D}}{2+\gamma n}, i \neq 0 .
$$

3. The equilibrium profits of the foreign subsidiary, the domestic subsidiary, and the domestic competitors, respectively, are

$$
\pi_{0}^{F}=\frac{\alpha_{F}^{2}}{4}, \pi_{0}^{D}=\left(\frac{\alpha_{D}}{2+\gamma n}\right)^{2} \text {, and } \pi_{i}^{D}=\left(\frac{\alpha_{D}}{2+\gamma n}\right)^{2}, i \neq 0 .
$$

Proof: all proofs are in the Appendix.

Given that the domestic and foreign markets are sealed from one another, it is unsurprising that the optimal transfer price, $p^{D}$, is the domestic firm's marginal cost. This result replicates the findings in Hirshleifer (1956), which illustrates that the optimal transfer price for an internal transfer is the product's marginal cost when markets are sealed and the downstream division is a price setter. In such a setting, the only consequence to raising transfer prices above zero is to induce double marginalization in the foreign subsidiary and, consequently, lower the profits of both the foreign subsidiary and the multinational.

\subsection{Quantity Competition with a Gray Market Entrant}

In this subsection, we incorporate a gray market. ${ }^{9}$ We define the gray market as a domestic firm (denoted as firm $g$ in the domestic market) that purchases the foreign subsidiary's product in the foreign market at a cost of $\alpha_{F}-q_{0}^{G F}$ (i.e., the market price of the product being sold in the foreign market) and then resells it in the domestic market. When the gray market firm is included in the economy, it becomes the domestic subsidiary's $n+1^{\text {th }}$ domestic competitor. Note that the gray market firm has a capacity

\footnotetext{
${ }^{9}$ We use the superscript GF to denote the foreign market and $G D$ to denote the domestic market in the gray market setting.
} 
constraint, in that it can only sell as much product as the foreign subsidiary sells in the foreign market.

Additionally, we assume that, like the other domestic competitors, the gray market firm sells a substitute good differentiated from the domestic subsidiary's product by $\gamma \cdot{ }^{10}$ This assumption is based on the observation that products produced for foreign markets often differ from their domestic counterparts to meet local preferences (e.g., colors, sizes) or local regulations (e.g., emissions, labeling). Furthermore, when these products are reimported domestically, evidence suggests that at least some of the domestic consumers prefer the foreign product because of this differentiation. For example, the Mexican version of Coca-Cola is often reimported through unofficial channels to the United States. The Mexican version tastes different than the American one, and is sometimes preferred by American consumers. ${ }^{11}$

Finally, in this setting, the foreign market is now comprised of consumers who are interested in purchasing the foreign product both for consumption and for resale back into the domestic market. ${ }^{12}$ As in the sealed market setting, we assume that end user quantities and prices are strictly positive and transfer prices are weakly positive. Figure 2 shows the timeline of the game including gray markets.

\begin{tabular}{|c|c|c|c|}
\hline $\begin{array}{l}\text { The multinational } \\
\text { chooses the foreign } \\
\text { transfer price, } p \text {. }\end{array}$ & $\begin{array}{l}\text { The foreign subsidiary chooses } \\
\text { quantity in the foreign market. } \\
\text { In the foreign market, consumers } \\
\text { purchase and the subsidiary's }\end{array}$ & $\begin{array}{l}\text { Quantities are simultaneously } \\
\text { chosen by the domestic } \\
\text { subsidiary and competitors in } \\
\text { the domestic market. }\end{array}$ & $\begin{array}{l}\text { In the domestic } \\
\text { market, consumers } \\
\text { purchase and firm } \\
\text { profits are realized. }\end{array}$ \\
\hline
\end{tabular}

Figure 2: Timeline in a Gray Market Setting

\footnotetext{
${ }^{10}$ For tractability, we assume the gray market good has the same degree of product differentiation as the goods of domestic competitors. In robustness checks (see footnote 12), we relax this assumption with no impact on the interpretation of our results, although the expressions are substantially more complex.

${ }^{11}$ Gray Markets - a gray area of business ethics, Jerusalem Post, January $13^{\text {th }}, 2006$.

${ }^{12}$ Although the presence of a gray market firm could increase the size of the foreign market, for tractability we have not modeled changes to the intercept of the inverse demand function. However our results are robust to using a larger intercept for the foreign subsidiary's inverse demand function, $\alpha_{F}$, in the gray market setting. A larger foreign intercept increases the likelihood that the multinational enters the foreign market (Proposition 6) and that the gray market’s capacity constraint is non-binding (Proposition 1).
} 
The foreign subsidiary chooses $q_{0}^{G F}$ to maximize its profits:

$$
\underset{q_{0}^{G F}>0}{\operatorname{aax}} \pi_{0}^{G F}=q_{0}^{G F}\left[\alpha_{F}-q_{0}^{G F}\right]-p q_{0}^{G F}
$$

The domestic subsidiary chooses $q_{0}^{G D}$ to maximize its profits:

$$
\underset{q_{0}^{G D}>0}{\operatorname{Max}} \pi_{0}^{G D}=q_{0}^{G D}\left[\alpha_{D}-q_{0}^{G D}-\sum_{j \neq 0, g} \gamma q_{j}^{G D}-\gamma q_{g}^{G D}\right]+p q_{0}^{G F}
$$

The $n$ domestic competitors each choose $q_{i}^{G D}, i \neq 0, g$, to maximize their profits:

$$
\underset{q_{i}^{G D}>0}{\operatorname{Max}} \pi_{i}^{G D}=q_{i}^{G D}\left[\alpha_{D}-q_{i}^{G D}-\sum_{j \neq i, g} \gamma q_{j}^{G D}-\gamma q_{g}^{G D}\right], i \neq 0, g
$$

The gray market firm chooses $q_{g}^{G D}$ to maximize its profits:

$$
\begin{aligned}
& \underset{q_{g}^{G D} \geq 0}{\operatorname{Max}} \pi_{g}^{G D}=q_{g}^{G D}\left[\alpha_{D}-q_{g}^{G D}-\sum_{j \neq 0, g} \gamma q_{j}^{G D}-\gamma q_{0}^{G D}\right]-q_{g}^{G D}\left[\alpha_{F}-q_{0}^{G F}\right] \\
& \text { subject to: } q_{g}^{G D} \leq q_{0}^{G F} .
\end{aligned}
$$

Jointly solving the first order conditions for Equations (6), (7), and (8) yields equilibrium quantities as a function of the transfer price and foreign quantity, $q_{i}^{G D}\left(p, q_{0}^{G F}\right), i=0, \ldots, n, g$. Solving the first order condition in Equation (5) yields the equilibrium foreign quantity as a function of the transfer price, denoted $q_{0}^{G F}(p)$. Substituting $q_{0}^{G F}(p)$ into $q_{i}^{G D}\left(p, q_{0}^{G F}\right), i=0, \ldots, n, g$ yields $q_{i}^{G D}(p), i=0, \ldots, n, g$. Given these quantities the firm sets the optimal transfer price, $p$, to maximize the sum of the profits of its domestic and foreign division.

$$
\underset{p}{\operatorname{Max}}=\pi_{0}^{G D}(p)+\pi_{0}^{G F}(p)
$$

Solving (9) yields the optimal transfer price, $p^{G D}$. Substituting $p^{G D}$ into both $q_{i}^{G D}(p), i=0, \ldots, n, g$ and $q_{0}^{G F}(p)$ yields optimal quantities $q_{i}^{G D}, i=0, \ldots, n, g$ and $q_{0}^{G F}$, 
respectively. Using these optimal quantities and $p^{G D}$ yields optimal profits for each domestic firm $\pi_{i}^{G D}, i=0, \ldots, n, g$ and the foreign subsidiary $\pi_{0}^{G F} \cdot{ }^{13}$ These results are summarized in Lemma 2.

Lemma 2. With a gray market entrant, the equilibrium outcomes are as follows, where $A \equiv(2+\gamma(1+n)):$

1. The equilibrium quantities chosen by the foreign subsidiary, the domestic firms, and the gray market firm, respectively, are

$$
\begin{aligned}
& q_{0}^{G F}=\frac{\alpha_{F}-p^{G D}}{2}, \quad q_{i=0, \ldots, n}^{G D}=\frac{1}{A}\left[\alpha_{D}+\frac{\gamma\left(\alpha_{F}+p^{G D}\right)}{2(2-\gamma)}\right], \text { and } \\
& q_{g}^{G D}=\frac{1}{A}\left[\alpha_{D}-\frac{(2+\gamma n)\left(\alpha_{F}+p^{G D}\right)}{2(2-\gamma)}\right] .
\end{aligned}
$$

2. The optimal internal transfer price to the foreign subsidiary

$$
\text { is } p^{G D}=\frac{\gamma\left(4 \alpha_{D}+\gamma\left(\alpha_{F}-2 \alpha_{D}\right)\right)}{(2-\gamma)^{2} A^{2}-\gamma^{2}} \text {. }
$$

3. The equilibrium profits of the foreign subsidiary, the domestic subsidiary, the domestic competitors, and the gray market firm, respectively, are

$$
\begin{aligned}
& \pi_{0}^{G D}=\left(\frac{1}{A}\right)^{2}\left(\alpha_{D}+\frac{\gamma\left(\alpha_{F}+p^{G D}\right)}{2(2-\gamma)}\right)^{2}+p^{G D}\left(\frac{\alpha_{F}-p^{G D}}{2}\right), \\
& \pi_{0}^{G F}=\left(\frac{\alpha_{F}-p^{G D}}{2}\right)^{2}, \pi_{i=1, \ldots, n}^{G D}=\left(\frac{1}{A}\right)^{2}\left(\alpha_{D}+\frac{\gamma\left(\alpha_{F}+p^{G D}\right)}{2(2-\gamma)}\right)^{2}, \text { and } \\
& \pi_{g}^{G D}=\left(\frac{1}{A}\right)^{2}\left(\alpha_{D}-\frac{(2+\gamma n)\left(\alpha_{F}+p^{G D}\right)}{2(2-\gamma)}\right)^{2} .
\end{aligned}
$$

\footnotetext{
${ }^{13}$ For robustness, we also solve the model using three alternate specifications. In the first specification, we make firm 0 's product and the gray market good perfect substitutes which are both differentiated from the $n$ domestic competitors by $\gamma$. In the second specification, we make firm 0 's product and those of its $n$ domestic competitors perfect substitutes which are differentiated from the gray market product by $\gamma$. In the third specification we allow the domestic consumers to exhibit a higher willingness to pay for the domestic goods than gray market goods (following intuition from Ahmadi and Yang (2000)). The tenor of all of the paper's results remain unchanged using any of the alternate specification.
} 
Finally, recall that the gray market quantity is subject to two constraints. First, the gray market quantity must be non-negative (the non-negativity constraint). Second, the gray market supply is limited to the quantity sold by the foreign subsidiary (the capacity constraint). We restrict our attention to the case where both constraints are met. The following observation summarizes a few relevant properties of these constraints.

Observation 1. In a gray market setting, the quantity constraints have the following properties:

1. Ceteris paribus, a decrease in transfer price $p^{G D}$ makes it more likely that both gray market quantity constraints are met.

2. If $\frac{\alpha_{D}}{\alpha_{F}}>\frac{2+n \gamma}{2-\gamma}$, then meeting the capacity constraint is sufficient. There exists a threshold $\bar{R}$ such that both constraints are met when $\bar{R}>\frac{\alpha_{D}}{\alpha_{F}}>\frac{2+n \gamma}{2-\gamma}$.

3. If $\frac{\alpha_{D}}{\alpha_{F}}<\frac{2+n \gamma}{2-\gamma}$, then meeting the non-negativity constraint is sufficient. There exists a threshold $\underline{R}$ such that both constraints are met when $\underline{R}<\frac{\alpha_{D}}{\alpha_{F}}<\frac{2+n \gamma}{2-\gamma}$.

4. Both constraints are met whenever $\frac{\alpha_{D}}{\alpha_{F}} \in[\underline{R}, \bar{R}]$.

Decreasing the transfer price increases the quantity sold by the foreign subsidiary, which in turn lowers the retail price in the foreign market (i.e., the gray market's cost base). Hence the gray market purchases a higher quantity, and the non-negativity constraint is more likely to be met. Further, the quantity increase by the foreign subsidiary is larger than the increase in the gray market's quantity, making the capacity constraint more likely to be met as well.

Intuitively, the constraints on the gray market quantities represent the following tradeoff: if the domestic market is sufficiently large relative to the foreign market, then the demand for gray market goods is strong but the supply (constrained by the smaller foreign market) may not be available. On the other hand, if the foreign market is 
sufficiently large relative to the domestic market, then supply is not a problem but there may be too little demand from the gray market competitor, because a relatively large foreign market also increases the gray market's cost base, making it less competitive when it reimports domestically.

Our first result relates to the multinational firm's optimal internal transfer price, and is formalized below in Proposition 1.

Proposition 1: When a gray market firm is present in the economy, the multinational firm's optimal transfer price to the foreign subsidiary, $p^{G D}$, has the following properties.

1. $p^{G D}$ is a function of domestic competition and is decreasing in the number of domestic competitors.

2. $p^{G D}$ converges to the optimal transfer price in a sealed market, $p^{D}$, as the domestic market approaches perfect competition $(n \rightarrow \infty)$ or as the products become perfectly differentiated $(\gamma \rightarrow 0)$.

3. $p^{G D}$ is strictly above marginal cost for all $\gamma \in(0,1]$.

While transfer prices to the foreign subsidiary are strictly above marginal cost in the gray market setting (consistent with Hirshleifer 1956), they also decrease as competitive pressures increase in the domestic market. This result arises due to two forces. First, as the number of competitors increases in the domestic market, the gray market firm faces increasingly lower prices domestically. Thus, increasing the cost base of the gray market firm with higher transfer prices has a smaller benefit when comparatively low prices in the domestic market already reduce the gray market's competitiveness. At the extreme (perfect competition), the entry of a gray market player has no impact on the domestic firm's consumer demand. Second, as $n$ increases, there is an increased incentive on the multinational's part to maximize its profits in the less competitive foreign market. Both factors lead to a deflationary pressure on the price of internal transfers as $n$ increases. Separately, as gray market goods become perfectly differentiated from domestic goods, they have no impact on the domestic firm's consumer demand and thus the firm's optimal transfer price is the same as in a sealed market. 
Finally, points 1 and 3 provide an important extension to the results in Hirshleifer (1956). While Hirshleifer illustrates that the optimal transfer price between affiliated segments is a function of the nature of downstream competition, we illustrate that, conditional on there being product leakage from the downstream to the upstream market, the optimal transfer price is additionally a function of the nature of upstream competition.

\subsection{Arm's Length Transfer Prices}

A firm's discretion to offer intracompany discounts between its subsidiaries is restricted by legislation affecting member countries of the Organization for Economic Co-operation and Development (“OECD nations”) to follow the arm's length standard. In

the United States, the reported transfer price must be "consistent with the results that would have been realized if uncontrolled taxpayers had engaged in the same transaction under the same circumstances” (Treasury Regulations §1.482-1(b)(1)). In our setting, we take the comparable uncontrolled price to be the price that the domestic segment would have charged an unrelated foreign third party for its product. When calculating a firm's arm's length transfer price, we additionally take compliance with the standard as given, as the purpose of this exercise is to assess the profitability and social welfare consequences of a firm shifting from its optimal transfer price to an arm's length transfer price, were the arm's length standard perfectly enforceable.

We derive the arm's length transfer price by solving for the transfer price which maximizes the domestic subsidiary's profits. In an economy with sealed market segments, we solve as before, but the multinational maximizes (10) instead of (4) to obtain the arm's length transfer price.

$$
\underset{p}{\operatorname{Max}}=\pi_{0}^{D}(p)
$$

In an economy with a gray market entrant, we again solve as before except the multinational maximizes (11) instead of (9) to obtain the arm's length transfer price.

$$
\underset{p}{\operatorname{Max}}=\pi_{0}^{G D}(p)
$$

The resulting arm's length transfer prices are presented in Lemma 3. 
Lemma 3. The arm's length transfer prices that maximize the domestic subsidiary's profits are as follows, where $A \equiv(2+\gamma(1+n))$ :

1. In a sealed market, the arm's length transfer price is $p^{\text {Darm }}=\frac{\alpha_{F}}{2}$.

2. In a market with a gray market entrant, the arm's length transfer price is

$$
p^{G D a r m}=\frac{\alpha_{D}(2 \gamma)(2-\gamma)+\alpha_{F}\left((2-\gamma)^{2} A^{2}+\gamma^{2}\right)}{2(2-\gamma)^{2} A^{2}-\gamma^{2}} .
$$

Proposition 2. In both sealed market and gray market settings, the arm's length transfer prices are strictly higher than the transfer prices that maximize the multinational firm's profit.

Corollary 1. With a gray market entrant, the arm's length transfer price is decreasing in the competitiveness of the domestic market. The arm's length transfer price in a gray market setting converges to that in a sealed market as the domestic market approaches perfect competition $(n \rightarrow \infty)$ or as the products become perfectly differentiated $(\gamma \rightarrow 0)$.

Arm's length transfer prices are strictly larger than the multinational's optimal transfer price because the objective functions in (10) and (11) no longer incorporate profits from the foreign subsidiary. Because the foreign division's profit function is decreasing in the transfer price, its removal no longer disciplines the multinational's transfer price lower. This, in turn, leads to strictly larger transfer prices. Next, as in Corollary 1, the arm's length transfer price in a gray market setting is decreasing in the number of competitors in the domestic market. Finally, as the domestic market becomes perfectly competitive, the entry of a gray market player has no impact on the domestic firm's consumer demand. Similarly, as gray market goods become perfectly differentiated from domestic goods, they have no impact on the domestic firm's consumer demand and thus the firm behavior resembles that of a sealed market. 


\subsection{Social Welfare}

In this subsection, we assess the social welfare ramifications (in a single period) of mandating the arm's length transfer prices in Lemma 3 rather than permitting the multinational to choose its optimal transfer price as presented in Lemmas 1 and $2 .{ }^{14}$ For tractability purposes, we assume in this subsection that the domestic firm is a monopolist in the domestic market (i.e., $n=0$ ), as ceteris paribus, the social welfare ramifications of a shift in transfer pricing regimes should be more pronounced the less competitive the setting. ${ }^{15}$ We additionally assume that, from a social welfare perspective, the domestic government values one dollar of domestic corporate profit as equal to one dollar of domestic consumer surplus. As tax revenues are derived from producer surplus and as we have already assumed that tax rates are identical across international jurisdictions, domestic social welfare is not a function of domestic tax rates in our analysis.

While we assess the changes in social surplus following a shift to arm's length transfer pricing for all economies (domestic, foreign and worldwide), the primary focus of this section is the effect of mandated arm's length transfer pricing on domestic social surplus. The reason is that, while the OECD transfer pricing regulations were initiated to maintain tax fairness among member and several non-member nations, the decision of a domestic government to enforce the standards is presumably initiated in order to maximize domestic social surplus. For example, in 2009 the U.S. government mandated an increase in transfer pricing enforcement to shore up its tax base. ${ }^{16}$

We define domestic social welfare in the sealed market setting, $S W_{D}^{p}\left(p, q_{0}^{D}, q_{0}^{F}\right)$, as the sum of domestic consumer and producer surplus. This surplus is a function of the quantity, $q_{0}^{D}$, produced for the domestic economy plus the profits from the quantity, $q_{0}^{F}$, produced for the foreign market and repatriated at transfer price $p$.

\footnotetext{
${ }^{14}$ For additional analysis of the combined social surplus ramifications of gray markets see Maskus and Chen (2004).

15 That is, increasing the cost base of an already comparatively high-cost gray market producer has a smaller domestic welfare impact as the number of domestic competitors increases.

${ }^{16}$ www.transferpricing.com/pdf/US_Commissioner\%20Doug\%20Shulman's\%20Remarks\%20to\%20OECD.pdf
} 


$$
S W_{D}^{p}=\underbrace{\alpha_{D}\left(q_{0}^{D}\right)-\frac{\left(q_{0}^{D}\right)^{2}}{2}}_{\text {domestic production }}+\underbrace{p q_{0}^{F}}_{\begin{array}{c}
\text { repatriated } \\
\text { profit }
\end{array}}
$$

In the sealed market setting, we define the change in domestic social welfare following a shift from the multinational's optimal transfer price to the multinational's arm's length transfer price as $\Delta S W_{D}^{p}=S W_{D}^{p^{\text {Darm }}}-S W_{D}^{p^{D}}$.

The inclusion of the gray market firm shifts the domestic competitive landscape from a monopoly to a Cournot duopoly. We define domestic social welfare in the gray market setting, $S W_{G D}^{P}\left(p, q_{0}^{G D}, q_{g}^{G D}, q_{0}^{G F}\right)$, as the sum of domestic consumer and producer surplus. The surplus from the domestic production follows methods established by Singh and Vives (1984). The repatriated profits are based on the quantity, $q_{0}^{G F}$, produced for the foreign market and internal transfer price $p$.

$$
S W_{G D}^{p}=\underbrace{\alpha_{D}\left(q_{0}^{G D}+q_{g}^{G D}\right)-\frac{1}{2}\left(\left(q_{0}^{G D}\right)^{2}+2 \gamma q_{0}^{G D} q_{g}^{G D}+\left(q_{g}^{G D}\right)^{2}\right)}_{\text {domestic production }}+\underbrace{p q_{G}^{G F}}_{\substack{\text { repatriated } \\ \text { profit }}}
$$

In the gray market setting, we define the change in domestic social welfare following a shift from the multinational's optimal transfer price to the multinational's arm's length transfer price as $\Delta S W_{G D}^{p}=S W_{G D}^{p^{G D a r m}}-S W_{G D}^{p^{G D}}$.

Next, we similarly define the foreign economy's social welfare function in both the sealed and gray market settings.

$$
\begin{gathered}
S W_{F}^{p}=\underbrace{\alpha_{F}\left(q_{0}^{F}\right)-\frac{\left(q_{0}^{F}\right)^{2}}{2}}_{\text {foreign production }}-\underbrace{p q_{0}^{F}}_{\begin{array}{c}
\text { repatriated } \\
\text { profit }
\end{array}} \\
S W_{G F}^{p}=\underbrace{\alpha_{F}\left(q_{0}^{G F}\right)-\frac{\left(q_{0}^{G F}\right)^{2}}{2}}_{\text {foreign production }}-\underbrace{p q_{0}^{G F}}_{\begin{array}{c}
\text { repatriated } \\
\text { profit }
\end{array}}
\end{gathered}
$$


Note that the repatriated profits are subtracted from each welfare function. As above, $\Delta S W_{F}^{p}$ and $\Delta S W_{G F}^{p}$ represent the change in foreign social welfare following a shift from the multinational's optimal transfer price to the multinational's arm's length transfer price in the sealed and gray market settings, respectively.

To obtain total social welfare (i.e., encompassing both markets) under a given transfer pricing regime in a sealed market setting, we combine the social welfare functions in (12) and (14) to form (16) below. Similarly, to obtain total social welfare in a gray market setting we combine (13) and (15) to form (17) below.

$$
\begin{gathered}
S W_{D+F}^{p}=\underbrace{\alpha_{D}\left(q_{0}^{D}\right)-\frac{\left(q_{0}^{D}\right)^{2}}{2}}_{\text {domestic production }}+\underbrace{\alpha_{F}\left(q_{0}^{F}\right)-\frac{\left(q_{0}^{F}\right)^{2}}{2}}_{\text {foreign production }} \\
S W_{G D+G F}^{p}=\underbrace{\alpha_{D}\left(q_{0}^{G D}+q_{g}^{G D}\right)-\frac{1}{2}\left(\left(q_{0}^{G D}\right)^{2}+2 \gamma q_{0}^{G D} q_{g}^{G D}+\left(q_{g}^{G D}\right)^{2}\right)}_{\text {domestic production }}+\underbrace{\alpha_{F}\left(q_{0}^{G F}\right)-\frac{\left(q_{0}^{G F}\right)^{2}}{2}}_{\text {foreign production }}
\end{gathered}
$$

Note that the repatriated profits are no longer a part of the total social welfare functions in (16) and (17), as the repatriated profit component of the domestic and foreign social surplus functions cancel each other out. Finally, $\Delta S W_{D+F}^{p}$ and $\Delta S W_{G D+G F}^{p}$ represent the change in total social welfare following a shift from the multinational's optimal transfer price to the multinational's arm's length transfer price in the sealed and gray market settings, respectively.

Proposition 3. When market segments are sealed, mandating a shift from the multinational's optimal transfer price, $p^{D}$, to an arm's length transfer price, $p^{\text {Darm }}$, has the following results.

1. The profit of the domestic subsidiary is higher under arm's length transfer pricing (i.e., $\pi_{0}^{D p^{D a r m}}>\pi_{0}^{D p^{D}}$ ).

2. The overall profit of the multinational firm is lower under arm's length pricing (i.e., $\pi_{0}^{D p^{D a r m}}+\pi_{0}^{F p^{D a r m}}<\pi_{0}^{D p^{D}}+\pi_{0}^{F p^{D}}$ ). 
3. Arm's length transfer pricing strictly increases domestic social surplus (i.e., $\left.\Delta S W_{D}^{p}>0\right)$.

4. Arm's length transfer pricing strictly decreases both foreign social surplus (i.e., $\Delta S W_{F}^{p}<0$ ) and total social surplus (i.e., $\Delta S W_{D+F}^{p}<0$ ).

When there is no product leakage between market segments, a switch to arm's length transfer pricing does indeed strictly increase domestic social welfare (as arm's length transfer pricing maximizes the foreign profits repatriated back to the domestic firm without affecting competition in the domestic setting), but leaves the multinational, foreign economy, and economy as a whole worse off due to the double marginalization of the foreign subsidiary.

Proposition 4. In a gray market setting, mandating a shift from the firm's optimal transfer price, $p^{G D}$, to an arm's length transfer price of, $p^{G D \text { arm }}$, has the following results.

1. The profit of the domestic subsidiary is higher under arm's length transfer pricing (i.e., $\pi_{0}^{G D p^{a r m}}>\pi_{0}^{G D p^{D}}$ ).

2. The overall profit of the multinational firm is lower under arm's length pricing (i.e., $\pi_{0}^{G D p^{a r m}}+\pi_{0}^{G F p^{a r m}}<\pi_{0}^{G D p^{D}}+\pi_{0}^{G F p^{D}}$ ).

3. There exists a threshold $R^{*}$ such that:

a.) If $\frac{\alpha_{D}}{\alpha_{F}}>R^{*}$ then domestic social surplus is lower under arm's length pricing (i.e., $\Delta S W_{G D}^{p}<0$ ).

b.) If $\frac{\alpha_{D}}{\alpha_{F}}<R^{*}$ then domestic social surplus is higher under arm's length pricing (i.e., $\Delta S W_{G D}^{p}>0$ ).

c.) If $\frac{\alpha_{D}}{\alpha_{F}}>\frac{11}{8}$ then $\Delta S W_{G D}^{p}<0$ for all $\gamma \in(0,1]$.

4. Arm's length transfer pricing strictly decreases both foreign social surplus (i.e., $\Delta S W_{G F}^{p}<0$ ) and total social surplus (i.e., $\Delta S W_{G D+G F}^{p}<0$ ). 
The intuition behind the first two points and the last point are similar to that of Proposition 3. Two countervailing forces provide the tension in the third point. On the one hand, a shift to arm's length transfer pricing increases the funds repatriated to the domestic market. This increases domestic social welfare by increasing the multinational's domestic profits. On the other hand, increasing the transfer price to the foreign market increases the gray market firm's cost base. This makes the gray market firm an even higher cost producer than it had originally been. The increased cost base makes the gray market both less profitable and a weaker competitor in the domestic market which in turn erodes consumer surplus. Thus, a shift to arm's length transfer pricing leads to a tension between two forces which push social welfare in opposite directions. This tension can lead to an erosion of domestic social welfare, if the domestic market is sufficiently larger than the foreign one. Figure 3 illustrates this tradeoff.

\section{$<<$ INSERT FIGURE 3 ABOUT HERE $>>$}

Finally, we investigate the circumstances under which the multinational's optimal transfer price also maximizes the domestic economy's social welfare. To derive the transfer price which maximizes domestic social welfare, we maximize (13) with respect to $p .{ }^{17}$ The results are presented in Lemma 4.

Lemma 4. In a gray market setting, the transfer price that maximizes the social welfare of the domestic economy is

$$
p^{G D S W}=\frac{\alpha_{F}\left(28-13 \gamma^{2}+2 \gamma^{4}\right)-2 \alpha_{D}(2-\gamma)^{2}}{68-35 \gamma^{2}+4 \gamma^{4}} .
$$

Proposition 5. In a gray market setting, the transfer price that maximizes the multinational's profits may also be the same one that maximizes the social welfare of the domestic economy that houses it. However, the arm's length transfer price is never the one that maximizes the social welfare of the domestic economy.

\footnotetext{
${ }^{17}$ As in the previous settings, we assume that transfer prices are weakly positive and all quantities and enduser prices are strictly positive.
} 
This result is at the nexus of normative and positive accounting research (see Watts and Zimmerman (1978)). Specifically, this result suggests that, in the presence of gray markets, the accounting choice that is best for the multinational may, in certain cases, also be the one that is best for the domestic economy that houses it. In contrast, an arm's length transfer price can never be the transfer price that is best for the domestic economy that houses the multinational.

The implications of Propositions 4-6 suggest a rethink to the social benefits of mandating arm's length transfer pricing for a domestic economy. In a sealed market setting, only the domestic economy is better off with arm's length transfer pricing. However, in the gray market setting, allowing the firm to set its own transfer price may lead to Pareto improvements for all economic participants when compared to the arm's length transfer pricing option, provided the domestic market is sufficiently larger than the foreign one. ${ }^{18}$ More broadly, the combined results question the role of regulation when an unregulated market can generate Pareto improvements to the laws imposed by regulators.

\subsection{Robustness - multinational entry into the foreign market}

Given that the multinational itself is the source of gray market goods, one way for it to avoid the increased competition in its domestic market is to choose not to enter the foreign market in the first place. In this subsection, we verify whether the multinational opts to address the gray market problem by avoiding entry. In particular, we analyze the multinational's decision to enter the foreign market and derive conditions under which the multinational is better off entering the foreign market despite the resulting gray market.

In a sealed market setting, entering the foreign market has no impact on domestic competition, so the multinational will always be better off entering the foreign market. In a gray market setting, however, entry reduces the domestic subsidiary's profits through increased competition. The multinational enters the foreign market when its expected

\footnotetext{
${ }^{18}$ Given that the multinational seeks to maximize aggregate profits, we assume that the profits of the multinational, and not those of its subsidiaries, are used to evaluate the possibility for Pareto improvements when changing transfer pricing regimes.
} 
profit in a gray market setting (from Lemma 2) exceeds the expected profit of a standalone domestic subsidiary in a sealed setting (from Lemma 1):

$$
\left(\pi_{0}^{G F}+\pi_{0}^{G D}\right)>\pi_{0}^{D}
$$

As in the social welfare analysis, we fix the number of domestic competitors at $n=0$ and solve (18) to derive the conditions under which the multinational enters the foreign market.

Proposition 6 There exists a threshold $R^{\text {entry }}$ such that for all $\frac{\alpha_{D}}{\alpha_{F}}<R^{\text {entry }}$ it is in the multinational's best interest to enter the foreign market.

Intuitively, the multinational enters the foreign market when the market is sufficiently large to offset the anticipated reduction in domestic profits. Failure to enter is most likely to occur when the gray market good is a close substitute and cannibalizes domestic sales (i.e., $\gamma$ very close to 1). Accordingly, this constraint only binds for relatively large $\gamma$. Interestingly, $R^{*}$, the threshold over which the domestic economy is worse off under arm's length pricing, is decreasing in $\gamma$ over the interval of $\gamma \in[0,1]$, so that when this constraint does bind, arm's length transfer pricing reduces domestic social welfare. Figure 4 presents an example where all three constraints (gray market capacity, gray market non-negativity, and multinational entry) are met, and where the domestic social surplus is higher when the firm sets its own transfer price versus mandating arm's length pricing.

\section{$<<$ INSERT FIGURE 4 ABOUT HERE $>>$}

\section{Conclusion}

Following the work of Hirshleifer (1956), we illustrate that a multinational's optimal transfer price to an affiliated foreign monopolist (i.e., a consolidated subsidiary) is strictly higher than marginal cost when goods produced for a foreign market are leaked back to the domestic market. We extend Hirshleifer's results by further defining the optimal transfer price in terms of the number of competitors in the domestic economy and 
the level of differentiation between the foreign and domestic products. More importantly, while Hirshleifer illustrates that the optimal transfer price between affiliated segments is a function of the nature of downstream competition, we illustrate that, conditional on there being product leakage from the downstream to the upstream market, the optimal transfer price is additionally a function of the nature of upstream competition.

We also illustrate that gray markets may cause unintended social welfare consequences when domestic governments mandate the use of arm's length transfer prices between international subsidiaries. Specifically, a shift to arm's length transfer pricing erodes domestic consumer surplus by making the gray market less competitive domestically. When the domestic market is sufficiently large relative to the foreign market, the domestic welfare destruction arising from this erosion dominates the domestic welfare gains that accompany a shift to arm's length transfer pricing. Additionally, we find that in the presence of a gray market, the transfer price that maximizes a multinational's profits may also be the same one that maximizes the social welfare of the domestic economy that houses it.

It should be noted, however, that the study provides only a partial equilibrium analysis. For example, tax rates are exogenously set to be equal across international jurisdictions despite the fact that governments clearly set tax rates strategically. A full equilibrium analysis would incorporate the objectives of domestic and foreign tax authorities and derive tax rates endogenously.

Additionally, the domestic government's social welfare preferences are set exogenously. Specifically, the analysis assumes that the government places an equal value on one dollar of consumer surplus and one dollar of producer surplus. If, for example, the government has a preference for generating tax revenues to creating consumer surplus, we may expect to see it favoring policy that places a higher value on producer surplus. However, there is also reason to expect the opposite to be true. First, Baron (1988, p. 467) suggests that, "if there is a strong electoral connection between benefits delivered to constituents and their electoral support, the legislature will choose a regulatory mandate that favors consumers over producer interests...”. Second, weighting the government's objective function toward consumer surplus may be particularly 
appropriate in a gray market setting, given the historic unwillingness of domestic governments to curtail gray market activity. If we weight the objectives of the government more heavily in favor of consumers, then the negative consequences to imposing the arm's length standard become even larger.

Despite the partial nature of the equilibrium, the findings provide several insights. First, the results suggest several avenues for tax regulators to more effectively allocate resources for enforcement of the arm's length standard. For example, targeting multinationals which observe little product leakage from foreign markets or which operate in domestic markets that are sufficiently competitive may lead to net welfare gains for the domestic economy. Conversely, focusing enforcement efforts on multinationals that work in industries where gray markets provide the only means of domestic competition may make the domestic economy worse off. Second, the results provide partial explanations for both the variation in intracompany discounts across multinationals, and the perceived lax attitude to transfer pricing regulation enforcement by governments. In the first case, intracompany discounts to foreign subsidiaries may be a function of both domestic competition and the homogeneity of a company's domestic and foreign products. In the second case, the appearance of lax enforcement may simply be a byproduct of regulators' disincentive to enforce transfer pricing regulations when the domestic market reaps benefits from increased competition. 


\section{REFERENCES}

Ahmadi , R., Yang, B. 2000. Parallel imports: Challenges from unauthorized distribution channels. Marketing Science 19, 279-294.Antia, K.D., Bergen, M., Dutta S. 2004. Competing with gray markets. Sloan Management Review 46(1), 63-69.

Assmus, G., Wiese, C., 1995. How to address the gray market threat using price coordination. Sloan Management Review 36, 31-41.

Arya, A., Mittendorf, B. 2007. Interacting of supply chain distortions: The pricing of internal transfers and external procurement. The Accounting Review 82(3), 551580.

Arya, A., Mittendorf, B. 2008. Pricing internal trade to get a leg up on external rivals. Journal of Economics \& Management Strategy 17(3), 709-731.

Arya, A., Mittendorf, B., Yoon, D. 2008. Friction in related party trade when a rival is also a customer. Management Science, forthcoming.

Baldenius, T., Melumad, N., Reichelstein,S., 2004. Integrating managerial and tax objectives in transfer pricing. The Accounting Review 79, 591-615.

Baron, D., 1988. Regulation and legislative choice. The RAND Journal of Economics. 19, 467-477.

Bernard, A, Jensen, J. Schott, P., 2005. Transfer pricing by U.S.-based multinational firms. US Census Bureau Center for Economic Studies Paper No. CES-WP- 0829. Available at SSRN: http://ssrn.com/abstract $=924573$.

Bulow, J., J. Geanakoplos, and P. Klemperer. 1985. Multimarket oligopoly: Strategic substitutes and complements. Journal of Political Economy 93, 488-511.

Copithorne, L. W., 1971. International corporate transfer prices and government policy. Canadian Journal of Economics 4, 324-341.

Göx, R. 2000. Strategic transfer pricing, absorption costing, and observability. Management Accounting Research 11, 327-348.

Ernst \& Young. 1999. Transfer pricing 1999 global survey: Practices, perceptions and trends in 19 countries for 2000 and beyond.

Ernst \& Young. 2003. Transfer pricing 2003 global survey: Practices, perceptions and trends in 22 countries plus tax authority approaches in 44 countries. 
Halperin, R., Srinidhi, B., 1987. The effects of U.S. income tax regulations' transfer pricing rules on allocative efficiency. The Accounting Review 62, 686-706.

Halperin, R., Srinidhi, B., 1991. U.S. income tax transfer-pricing rules and resource allocation: The case of decentralized multinational firms. The Accounting Review $66,141-157$.

Harris, D., Sansing, R., 1998. Distortions caused by the use of arm's-length transfer prices. The Journal of the American Taxation Association. Spring, 40-50.

Hirshleifer, J., 1956. On the economics of transfer pricing. The Journal of Business 29, 172-184.

Horst, T. 1971. The theory of the multinational firm: Optimal behavior under different tariff and tax rates. Journal of Political Economy 79, 1059-1072.

Johnson, N., 2006. Divisional performance measurement and transfer pricing of intangible assets. Review of Accounting Studies 11, 339-365.

Li, C., Robles, J., 2007. Product innovation and parallel trade. International Journal of Industrial Organization 25, 417-429.

Maskus, K., Chen, Y., 2004. Vertical price control and parallel imports: theory and evidence. Review of International Economics 12, 551-570.

Narayanan, V. G., Smith, M., 2000. Impact of competition and taxes on responsibility center organization and transfer prices. Contemporary Accounting Research 17, 497-529.

Samuelson, L., 1982. The multinational firm with arm's length transfer price limits. Journal of International Economics 13, 365-374.

Sansing, R., 1999. Relationship-specific investments and the transfer pricing paradox. Review of Accounting Studies 4, 119-134.

Singh, N., Vives, X., 1984. Price and Quantity Competition in a Differentiated Duopoly. The Rand Journal of Economics 15(4), 546-554.

Smith, M., 2002. Ex ante and ex post discretion over arm's length transfer prices. The Accounting Review 77, 161-184.

Watts, R., Zimmerman, J., 1978. Towards a positive theory of the determination of accounting standards. The Accounting Review 53, 112 -134. 


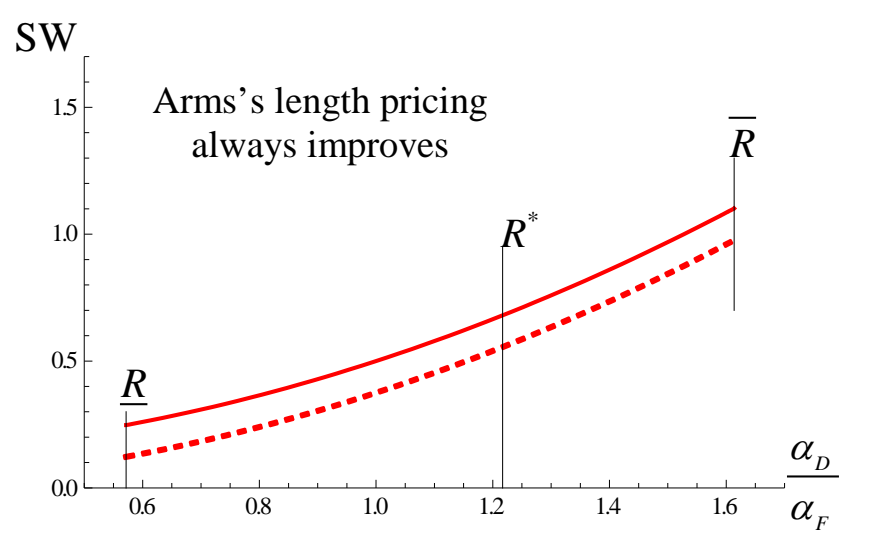

Sealed market setting

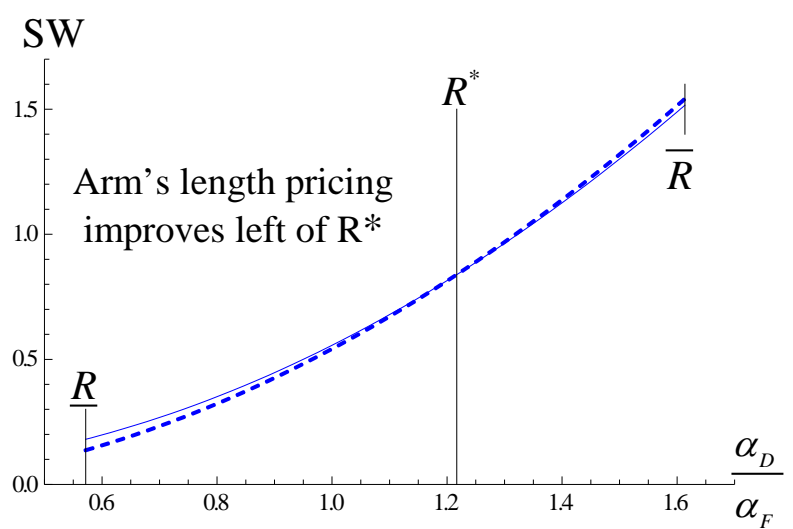

Gray market setting

Figure 3. Domestic social surplus under arm's length transfer pricing (solid line) versus the multinational's optimal pricing (dashed line). $(\gamma=0.2)$ 


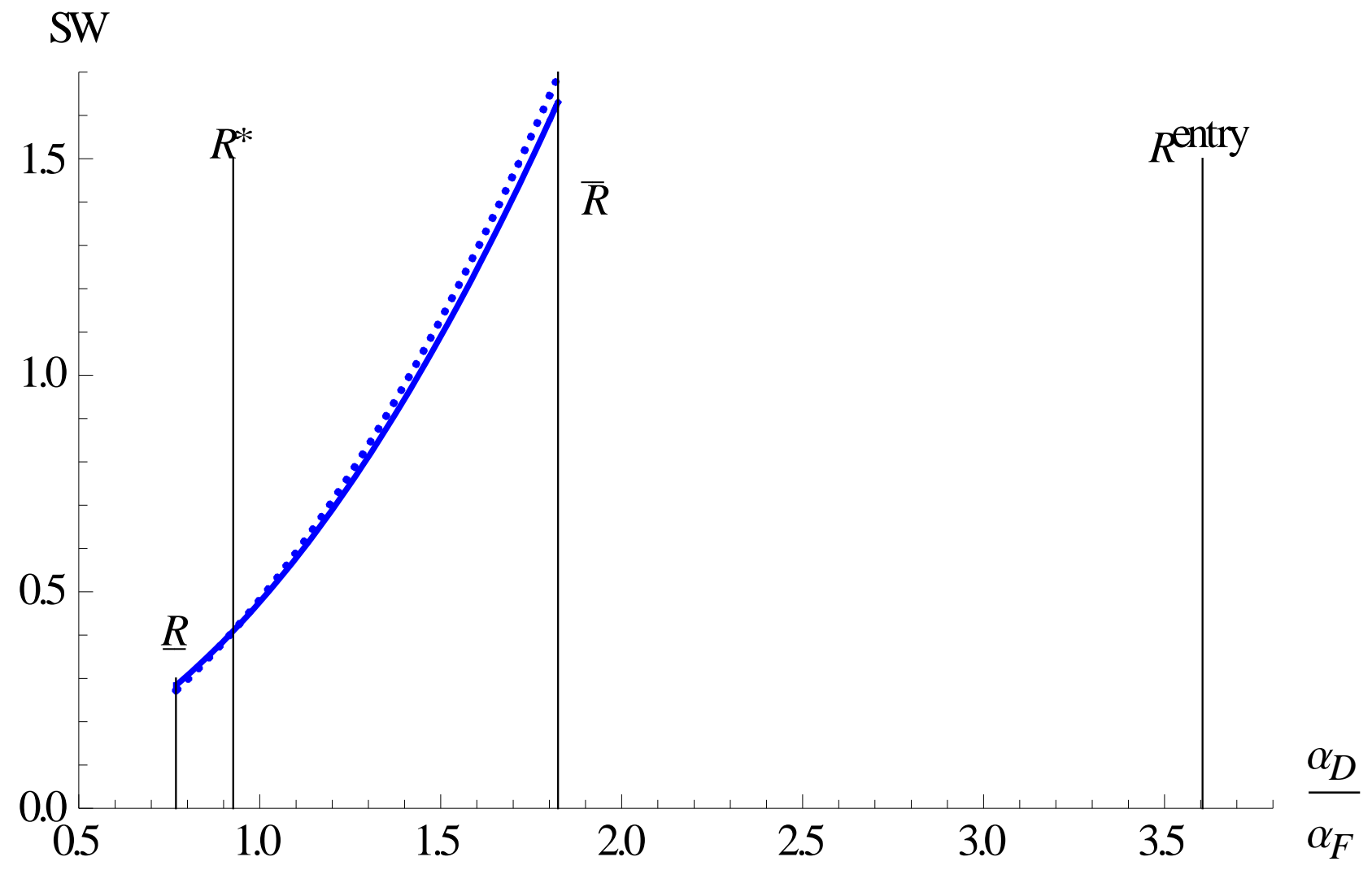

Figure 4. Domestic social surplus in a gray market setting under arm's length transfer pricing (solid line) versus the multinational's optimal pricing (dashed line). $(\gamma=0.55)$ 


\section{APPENDIX}

\section{Proof of Lemma 1}

In an economy with sealed market segments, firm 0 chooses $q_{0}^{F}$ to maximize Equation (1) and $q_{0}^{D}$ to maximize (2). Firm 0's rivals choose $q_{i}^{D}, i \neq 0$, to maximize (3). Solving the maximization problems jointly yields $q_{0}^{F}(p)$ and $q_{i}^{D}(\gamma, n), i=0, \ldots, n$, the equilibrium quantities in the foreign and domestic markets.

$$
\begin{aligned}
& q_{0}^{F}(p)=\frac{\alpha_{F}-p}{2} \\
& q_{0}^{D}(\gamma, n)=\frac{\alpha_{D}}{2+\gamma n} \\
& q_{i}^{D}(\gamma, n)=\frac{\alpha_{D}}{2+\gamma n}, i \neq 0
\end{aligned}
$$

Using $q_{0}^{F}(p), q_{0}^{D}(\gamma, n)$, and $q_{i}^{D}(\gamma, n), i \neq 0$, from (A1), (A2), and (A3) respectively, the multinational sets price $p$ to maximize profits in Equation (4). Solving the first-order condition of (4) with respect to $p$ yields $p^{D}$ in Lemma 1 . Substituting $p^{D}$ into (A1) yields $q_{0}^{F}$. Substituting $p^{D}$ and $q_{0}^{F}$ into Equation (1), $p^{D}, q_{0}^{F}, q_{0}^{D}(\gamma, n)$, and $q_{i}^{D}(\gamma, n), i \neq 0$, into Equation (2), and $q_{0}^{D}(\gamma, n)$ and $q_{i}^{D}(\gamma, n), i \neq 0$ into Equation (3), yields $\pi_{0}^{F}, \pi_{0}^{D}(\gamma, n), \pi_{i}^{D}(\gamma, n), i \neq 0$, respectively. This proves Lemma 1 .

\section{Proof of Lemma 2}

Firm 0 chooses $q_{0}^{G D}$ to maximize (6), firm 0 's $n$ domestic rivals choose $q_{i}^{G D}, i \neq 0, g$, to maximize (7), and firm $g$ chooses $q_{g}^{G D}$ to maximize (8). Solving the maximization problem jointly yields $q_{i}^{G D}\left(p, q_{0}^{G F}\right), i=0, \ldots, n, g$, the equilibrium quantities in the domestic market.

Next, firm 0 chooses $q_{0}^{G F}$ to maximize Equation (5). This leads to an equilibrium quantity in the foreign market of:

$$
q_{0}^{G F}(p)=\frac{\alpha_{F}-p}{2}
$$


Plugging $q_{0}^{G F}(p)$ into $q_{i}^{G D}\left(p, q_{0}^{G F}\right), i=0, \ldots, n, g$ yields $q_{i}^{G D}(p), i=0, \ldots, n, g$, the equilibrium quantities in the domestic market as follows:

$$
\begin{aligned}
& q_{0}^{G D}(p)=\frac{2 \alpha_{D}(2-\gamma)+\gamma\left(\alpha_{F}+p\right)}{2(2-\gamma)(2+\gamma+\gamma n)} \\
& q_{i}^{G D}(p)=\frac{2 \alpha_{D}(2-\gamma)+\gamma\left(\alpha_{F}+p\right)}{2(2-\gamma)(2+\gamma+\gamma n)}, i \neq 0, g \\
& q_{g}^{G D}(p)=\frac{2 \alpha_{D}(2-\gamma)-(2+\gamma n)\left(\alpha_{F}+p\right)}{2(2-\gamma)(2+\gamma+\gamma n)}
\end{aligned}
$$

Using $q_{0}^{G F}(p), q_{0}^{G D}(p), q_{i}^{G D}(p), i \neq 0, g$, and $q_{g}^{G D}(p)$ from (A4), (A5), (A6) and (A7), respectively, the multinational sets price $p$ to maximize profits in Equation (9). Solving the first-order condition of (9) with respect to $p$ yields $p^{G D}(\gamma, n)$ in Lemma 2. Substituting $p^{G D}(\gamma, n)$ into (A4), (A5), (A6), and (A7) yields $q_{0}^{G F}(\gamma, n)$ and $q_{i}^{G D}(\gamma, n), i=0, \ldots, n, g$. Substituting $p^{G D}(\gamma, n)$ and $q_{0}^{G F}(\gamma, n)$ into (5), $p^{G D}(\gamma, n)$, $q_{0}^{G F}(\gamma, n)$, and $q_{i}^{G D}(\gamma, n), i=0, \ldots, n, g$, into (6), $q_{i}^{G D}(\gamma, n), i=0, \ldots, n, g$, into (7), and $q_{i}^{G D}(\gamma, n), i=0, \ldots, n, g \quad$ and $\quad q_{0}^{G F}(\gamma, n) \quad$ into $\quad(8) \quad$ yields $\pi_{0}^{G F}(\gamma, n), \quad \pi_{0}^{G D}(\gamma, n)$, $\pi_{i}^{G D}(\gamma, n), i \neq 0, g$, and $\pi_{g}^{G D}(\gamma, n)$, respectively. This proves Lemma 2.

\section{Proof of Proposition 1}

The derivative of $p^{G D}(\gamma, n)$ with respect to $n$ is

$$
\frac{\partial p^{G D}(\gamma, n)}{\partial n}=-\frac{2(2-\gamma)^{2} \gamma^{2}\left(4 \alpha_{D}+\gamma\left(\alpha_{F}-2 \alpha_{D}\right)\right)(2+\gamma+\gamma n)}{\left((2-\gamma)^{2}(2+\gamma+\gamma n)^{2}-\gamma^{2}\right)^{2}}<0 \text {. (claim 1) }
$$

Next, $\lim _{\gamma \rightarrow 0} p^{G D}=0$ and $\lim _{n \rightarrow \infty} p^{G D}=0$ (claim 2).

Finally, marginal costs are assumed normalized to zero. Thus, $p^{G D}(\gamma, n)$ must be strictly greater than 0 for the optimal transfer price in the gray market setting to be higher than marginal cost, or: 


$$
p^{G D}(\gamma, n)=\frac{\gamma\left(4 \alpha_{D}+\gamma\left(\alpha_{F}-2 \alpha_{D}\right)\right)}{(2-\gamma)^{2}(2+\gamma+\gamma n)^{2}-\gamma^{2}}>0 .
$$

The numerator is strictly positive for all values of $\gamma \in(0,1]$, thus $p^{G D}(\gamma, n)$ is positive iff $(2-\gamma)^{2}(2+\gamma+\gamma n)^{2}>\gamma^{2}$. Because $(2-\gamma)^{2} \geq 1$ and $(2+\gamma+\gamma n)^{2}>2$, their product must be greater than $\gamma^{2} \in(0,1]$. Thus, the denominator of $p^{G D}(\gamma, n)$ is strictly positive, and hence $p^{G D}(\gamma, n)$ is also strictly positive for all values of $\gamma \in(0,1]$ (claim 3). This proves Proposition 1.

\section{Proof of Observation 1}

The derivatives of $q_{0}^{G F}(p)$ and $q_{g}^{G D}(p)$ with respect to $p$ are

$$
\frac{\partial q_{0}^{G F}(\gamma, n)}{\partial p}=-\frac{1}{2} \text { and } \frac{\partial q_{g}^{G D}(p)}{\partial p}=-\frac{2+n \gamma}{2(2-\gamma)(2+\gamma+\gamma n)} .
$$

Next, $q_{0}^{G F}(p)$ changes faster than $q_{g}^{G D}(p)$ because $\frac{2+n \gamma}{(2-\gamma)(2+\gamma+\gamma n)}<1$. Thus, as $p$ decreases, $q_{0}^{G F}(p)-q_{g}^{G D}(p)$ has a net increase. (Claim 1)

Both $q_{0}^{G F}(p)$ and $q_{g}^{G D}(p)$ are linear in $p$, so for sufficiently low $p$, both constraints are met. To obtain the cutoff values $p^{\text {Cap }}$ and $p^{\text {NonNeg }}$, we solve the expressions $q_{0}^{G F}(p)>q_{g}^{G D}(p)$ and $q_{g}^{G D}(p)>0$, respectively, for $p$. This yields:

$$
\begin{aligned}
& p<p^{C a p}=\frac{\alpha_{F}\left(6+3 n \gamma-\gamma^{2}(1+n)\right)-2 \alpha_{D}(2-\gamma)}{2+n \gamma(1-\gamma)-\gamma^{2}} \\
& p<p^{\text {NonNeg }}=\frac{2 \alpha_{D}(2-\gamma)-\alpha_{F}(2+n \gamma)}{2+n \gamma}
\end{aligned}
$$

For both gray market quantity constraints to be met, $p^{G D}(\gamma, n)$ must be less than $\min \left\{p^{\text {NonNeg }}, p^{\text {Cap }}\right\}$. The relevant cutoff depends on: 


$$
\begin{aligned}
\operatorname{sign}\left(p^{\text {NonNeg }}-p^{\text {Cap }}\right) & =\operatorname{sign}\left(\left(\alpha_{D}(2-\gamma)-\alpha_{F}(2+n \gamma)\right)\left[\frac{2(2-\gamma)(2+\gamma+n \gamma)}{(2+n \gamma)\left(2+n \gamma(1-\gamma)-\gamma^{2}\right)}\right]\right) \\
& =\operatorname{sign}\left(\alpha_{D}(2-\gamma)-\alpha_{F}(2+n \gamma)\right) \\
& =\operatorname{sign}\left(\frac{\alpha_{D}}{\alpha_{F}}(2-\gamma)-(2+n \gamma)\right)
\end{aligned}
$$

If $\frac{\alpha_{D}}{\alpha_{F}}>\frac{2+n \gamma}{2-\gamma}$, then $p^{\text {NonNeg }}>p^{\text {Cap }}$, and meeting the capacity constraint is sufficient.

$$
\begin{aligned}
p^{G D}(\gamma, n) & <p^{C a p}(\gamma, n) \\
\frac{\gamma\left(4 \alpha_{D}+\gamma\left(\alpha_{F}-2 \alpha_{D}\right)\right)}{(2-\gamma)^{2}(2+\gamma+\gamma n)^{2}-\gamma^{2}} & <\frac{\alpha_{F}\left(6+3 n \gamma-\gamma^{2}(1+n)\right)-2 \alpha_{D}(2-\gamma)}{2+n \gamma(1-\gamma)-\gamma^{2}} \\
\frac{\alpha_{D}}{\alpha_{F}} & <\frac{\left.24+24 n \gamma-2 \gamma^{2}\left(6+5 n-3 n^{2}\right)\right)-5 n \gamma^{3}(1+n)+\gamma^{4}(1+n)^{2}}{2\left(8-3 \gamma-3 \gamma^{2}+\gamma^{3}+n \gamma(2-\gamma)^{2}\right)} \equiv \bar{R}
\end{aligned}
$$

Thus, both constraints are met if $\bar{R}>\frac{\alpha_{D}}{\alpha_{F}}>\frac{2+n \gamma}{2-\gamma}$ (claim 2).

Alternatively, if $\frac{\alpha_{D}}{\alpha_{F}}<\frac{2+n \gamma}{2-\gamma}$ then $p^{\text {Cap }}>p^{\text {NonNeg }}$, and meeting the non-negativity constraint is sufficient.

$$
\begin{aligned}
p^{G D}(\gamma, n) & <p^{\text {NonNeg }}(\gamma, n) \\
\frac{\gamma\left(4 \alpha_{D}+\gamma\left(\alpha_{F}-2 \alpha_{D}\right)\right)}{(2-\gamma)^{2}(2+\gamma+\gamma n)^{2}-\gamma^{2}} & <\frac{2 \alpha_{D}(2-\gamma)-\alpha_{F}(2+n \gamma)}{2+n \gamma} \\
\frac{\alpha_{D}}{\alpha_{F}} & >\frac{(2-\gamma)(2+n \gamma)(2+\gamma+n \gamma)}{2\left(8-5 \gamma-2 \gamma^{2}+\gamma^{3}+n \gamma(2-\gamma)^{2}\right)} \equiv \underline{R}
\end{aligned}
$$

Thus, both constraints are met if $\underline{R}<\frac{\alpha_{D}}{\alpha_{F}}<\frac{2+n \gamma}{2-\gamma} \quad$ (claim 3).

Combining conditions in claims 2 and 3 proves claim 4, completing the proof.

\section{Proof of Lemma 3}

In an economy with sealed market segments, using $q_{0}^{F}(p), q_{0}^{D}(\gamma, n)$, and $q_{i}^{D}(\gamma, n), i \neq 0$, from (A1), (A2), and (A3) respectively, the multinational sets price $p$ to maximize domestic profits in Equation (10). Solving the first-order condition of (10) with 
respect to $p$ yields $p^{\text {Darm }}$ in Lemma 3. In an economy with a gray market firm, using $q_{0}^{G F}(p), q_{0}^{G D}(p), q_{i}^{G D}(p), i \neq 0, g$, and $q_{g}^{G D}(p)$ from (A4), (A5), (A6) and (A7), respectively, the multinational sets price $p$ to maximize domestic profits in (11). The first-order condition of (11) with respect to $p$ yields $p^{G D a r m}(\gamma, n)$ in Lemma 3. This proves Lemma 3.

\section{Proof of Proposition 2}

$p^{\text {Darm }}>0$ is clearly greater than $p^{D}$. To illustrate that $p^{G D a r m}(\gamma, n)>p^{G D}(\gamma, n)$, we show that $p^{G D \text { arm }}(\gamma, n) \leq p^{G D}(\gamma, n)$ cannot be true. If $p^{G D \text { arm }}(\gamma, n) \leq p^{G D}(\gamma, n)$, then:

$$
\frac{4 \alpha_{D} \gamma-2 \alpha_{D} \gamma^{2}+\alpha_{F}\left(B+\gamma^{2}\right)}{2 B-\gamma^{2}} \leq \frac{\gamma\left(4 \alpha_{D}+\gamma\left(\alpha_{F}-2 \alpha_{D}\right)\right)}{B-\gamma^{2}},
$$

where $A \equiv 2+\gamma(1+n)$ and $B \equiv A^{2}(2-\gamma)^{2}$.

Rearranging terms in (A8) yields $\frac{B\left(B \alpha_{F}-2 \gamma\left(\alpha_{D}(2-\gamma)+\alpha_{F} \gamma\right)\right)}{2 B^{2}-3 B \gamma^{2}+\gamma^{4}} \leq 0$. The denominator is quadratic and convex in $B$, it reaches a minimum at $B=\frac{3 \gamma^{2}}{4}$, and its two roots are $B=\frac{\gamma^{2}}{2}$ and $B=\gamma^{2}$. Thus, if $B>\gamma^{2}$, then the denominator is strictly positive. The proof of Proposition 1 establishes that $B>\gamma^{2}$ for all values of $n$ and $\gamma \in(0,1]$. Since $B>0$ for all $\gamma \in(0,1]$, the inequality in (A8) holds if $B \alpha_{F}-2 \gamma\left(\alpha_{D}(2-\gamma)+\alpha_{F} \gamma\right) \leq 0$. Rearranging the terms yields:

$$
\alpha_{F} \leq \frac{\gamma\left(4 \alpha_{D}+\gamma\left(\alpha_{F}-2 \alpha_{D}\right)\right)}{B-\gamma^{2}}=p^{G D}(\gamma, n) .
$$

If (A9) holds, then the multinational's optimal transfer price is equal to or larger than the intercept of the foreign market's inverse demand curve. If this is true, the foreign subsidiary produces zero or negative values for $q_{0}^{G F}$, a violation of this paper's assumptions. As such (A9), and in turn (A8), are never true. Thus, $p^{G D a r m}(\gamma, n)>p^{G D}(\gamma, n)$. This proves Proposition 2 . 


\section{Proof of Corollary 1}

The derivative of $p^{G D a r m}(\gamma, n)$ with respect to $n$ is

$$
\frac{\partial p^{G D a r m}(\gamma, n)}{\partial n}=-\frac{2(2-\gamma)^{2} \gamma^{2}\left(4 \alpha_{D}(2-\gamma)+3 \alpha_{F} \gamma\right)(2+\gamma+\gamma n)}{\left(32+\gamma\left(32 n+\gamma\left(-17-16 n+2(\gamma+(-2+\gamma) n)^{2}\right)\right)\right)^{2}}<0
$$

Further, $\lim _{\gamma \rightarrow 0} p^{\text {GDarm }}(\gamma, n)=\frac{\alpha_{F}}{2}$ and $\lim _{n \rightarrow \infty} p^{G \text { Garm }}(\gamma, n)=\frac{\alpha_{F}}{2}$. This proves Corollary 1.

\section{Proof of Proposition 3}

When markets are sealed from one another, Lemma 3 establishes that $p^{\text {Darm }}$ maximizes the domestic segment's profits in (10) and Lemma 1 establishes that $p^{D}$ maximizes the multinational's profits in (4). Proposition 2 establishes that $p^{D} \neq p^{D a r m}$. Thus the multinational is strictly better off with a transfer price of $p^{D}$ (claim 2) while the domestic firm is strictly better off with a transfer price of $p^{\text {Darm }}$ (claim 1). Substituting the values of $p^{\text {Darm }}$ and $p^{D}$ into $\Delta S W_{D}^{p}$ yields $\Delta S W_{D}^{p}=\frac{\alpha_{F}^{2}}{8}>0$ (claim 3). Substituting the values of $p^{\text {Darm }}$ and $p^{D}$ into $\Delta S W_{F}^{p}$ yields $\Delta S W_{F}^{p}=-\frac{9 \alpha_{F}^{2}}{32}<0$. Substituting the values of $p^{\text {Darm }}$ and $p^{D}$ into $\Delta S W_{D+F}^{p}$ yields $\Delta S W_{D+F}^{p}=-\frac{5 \alpha_{F}^{2}}{32}<0$ (claim 4). This proves Proposition 3.

\section{Proof of Proposition 4}

When a gray market firm is present, Lemma 3 establishes that $p^{\text {GDarm }}$ maximizes the domestic segment's profits in (11) and Lemma 2 establishes that $p^{G D}$ maximizes the multinational's profits in (9). Proposition 2 establishes that $p^{G D} \neq p^{G D a r m}$. Thus the multinational is strictly better off with a transfer price of $p^{G D}$ (claim 2) while the domestic firm is strictly better off with a transfer price of $p^{\text {GDarm }}$ (claim 1).

For notational convenience, define the following: 


$$
\begin{aligned}
D & \equiv 8\left(16-9 \gamma^{2}+\gamma^{4}\right)^{2}, \mathrm{E} \equiv 8\left(32-17 \gamma^{2}+2 \gamma^{4}\right)^{2} \\
F & \equiv \frac{4}{D}\left(384-272 \gamma-265 \gamma^{2}+198 \gamma^{3}+42 \gamma^{4}-36 \gamma^{5}-2 \gamma^{6}+2 \gamma^{7}\right) \\
G & \equiv \frac{4}{D}\left(64-120 \gamma+8 \gamma^{2}+74 \gamma^{3}-24 \gamma^{4}-8 \gamma^{5}+3 \gamma^{6}\right) \\
H & \equiv \frac{1}{D}\left(64-144 \gamma^{2}+68 \gamma^{4}-7 \gamma^{6}\right) \\
I & \equiv \frac{4}{E}\left(1536-1056 \gamma-961 \gamma^{2}+698 \gamma^{3}+168 \gamma^{4}-136 \gamma^{5}-8 \gamma^{6}+8 \gamma^{7}\right) \\
J & \equiv \frac{1}{E}\left(1536-1440 \gamma-480 \gamma^{2}+792 \gamma^{3}-96 \gamma^{4}-96 \gamma^{5}+24 \gamma^{6}\right) \\
K & \equiv \frac{1}{E}\left(448-368 \gamma^{2}+156 \gamma^{4}-41 \gamma^{6}+4 \gamma^{8}\right)
\end{aligned}
$$

Using the above notation, the social welfare functions are as follows:

$$
\begin{gathered}
S W_{G D}^{p^{G D}}=\alpha_{D}^{2} F-\alpha_{D} \alpha_{F} G-\alpha_{F}^{2} H=\frac{1}{\alpha_{F}^{2}}\left[\left(\frac{\alpha_{D}}{\alpha_{F}}\right)^{2} F-\frac{\alpha_{D}}{\alpha_{F}} G-H\right] \\
S W_{G D}^{p^{G D a r m}}=\alpha_{D}^{2} I-\alpha_{D} \alpha_{F} J+\alpha_{F}^{2} K=\frac{1}{\alpha_{F}^{2}}\left[\left(\frac{\alpha_{D}}{\alpha_{F}}\right)^{2} I-\frac{\alpha_{D}}{\alpha_{F}} J+K\right]
\end{gathered}
$$

We seek the sign of $S W_{G D}^{p^{G D a r m}}-S W_{G D}^{p^{G D}}$. Note that for all $\gamma \in(0,1], I>F$ and $J>G$.

$$
\operatorname{sign}\left(S W_{G D}^{p^{G D a r m}}-S W_{G D}^{p^{G D}}\right)=\operatorname{sign}\left(\left(\frac{\alpha_{D}}{\alpha_{F}}\right)^{2}(I-F)-\frac{\alpha_{D}}{\alpha_{F}}(J-G)+(K+H)\right)
$$

This expression is quadratic in $\frac{\alpha_{D}}{\alpha_{F}}$. For all $\gamma \in(0,1]$, it is a convex parabola with a minimum at $\frac{\alpha_{D}}{\alpha_{F}}=\frac{J-G}{2(I-F)}$ and two real roots. Designate the smaller root as root 1 and the larger as root 2. We also denote root 1 as $R^{*}$ : 


$$
\begin{aligned}
\text { root } 1 & =\frac{J-G-\sqrt{(J-G)^{2}-4(I-F)(K+H)}}{2(I-F)} \equiv R^{*} \\
& =\frac{2816-4416 \gamma^{2}+2544 \gamma^{4}-680 \gamma^{6}+85 \gamma^{8}-4 \gamma^{10}}{2\left(1024+608 \gamma-1424 \gamma^{2}-452 \gamma^{3}+660 \gamma^{4}+106 \gamma^{5}-123 \gamma^{6}-8 \gamma^{7}+8 \gamma^{8}\right)} \\
\text { root } 2 & =\frac{J-G+\sqrt{(J-G)^{2}-4(I-F)(K+H)}}{2(I-F)}=\frac{16-10 \gamma^{2}+\gamma^{4}}{2 \gamma(2-\gamma)}
\end{aligned}
$$

$R^{*}$ is the value of $\frac{\alpha_{D}}{\alpha_{F}}$ at which $S W_{G D}^{p^{G D a r m}}-S W_{G D}^{p^{G D}}$ flips from positive (i.e., where arm's length transfer pricing improves domestic social welfare) to negative (i.e., where arm's length transfer pricing decreases domestic social welfare). Next, the maximum feasible $\frac{\alpha_{D}}{\alpha_{F}}$ is $\bar{R}$, and for all $\gamma \in(0,1], \bar{R}$ is less than root 2. Thus, any $\frac{\alpha_{D}}{\alpha_{F}}>R^{*}$ satisfying the gray market constraints falls in region where arm's length transfer pricing decreases social welfare (because it cannot fall to the right of root 2). As a result, when $\frac{\alpha_{D}}{\alpha_{F}}>R^{*}$ then $S W_{G D}^{p^{G D a r m}}-S W_{G D}^{p^{G D}}<0$. If $\frac{\alpha_{D}}{\alpha_{F}}<R^{*}$ then $S W_{G D}^{p^{G D a r m}}-S W_{G D}^{p^{G D}}>0$. Below is a graphical representation for $\gamma=0.2$ (proof available from the authors upon request).

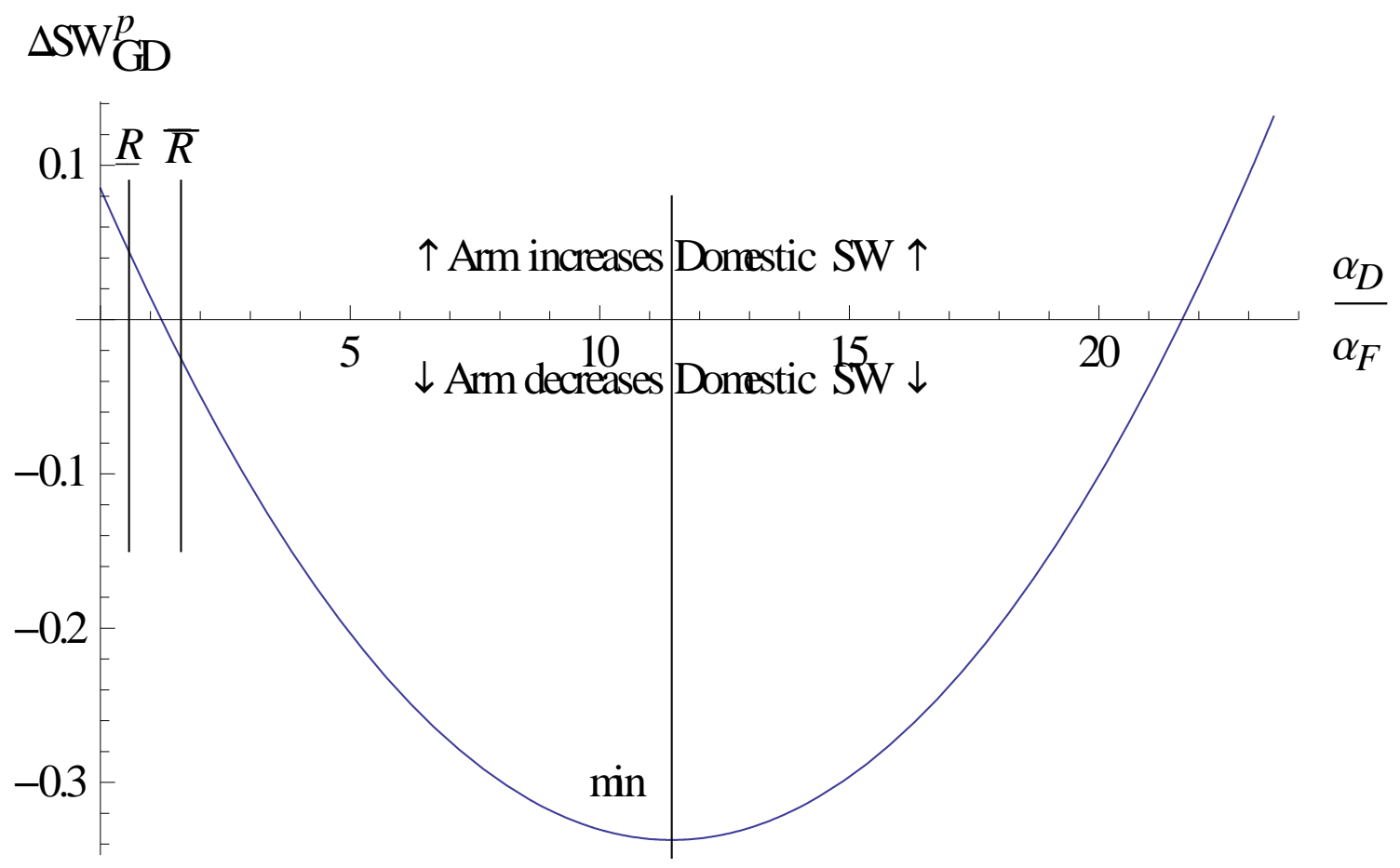


The last part of claim 3 establishes a sufficient condition for $\frac{\alpha_{D}}{\alpha_{F}}>R^{*} . R^{*}$ is decreasing in $\gamma$ over the interval of $\gamma \in[0,1]$. Thus $R^{*}$ is at its largest when $\gamma=0$, taking on the value $R^{*}=\frac{11}{8}$. Therefore, $\frac{\alpha_{D}}{\alpha_{F}}>\frac{11}{8}$ implies $S W_{G D}^{p^{G D a r m}}-S W_{G D}^{p^{G D}}<0$. (claim 3).

$S W_{G F}^{p}$ from equation (15) and $S W_{G D+G F}^{p}$ from equation (17) are both decreasing in $p$ provided $p \in\left[0, \alpha_{F}\right)$. As Proposition 2 establishes that $p^{G D a r m}(\gamma, n)>p^{G D}(\gamma, n)$, it follows that $\Delta S W_{G F}^{p}<0$ and $\Delta S W_{G D+G F}^{p}<0$ (claim 4). This proves Proposition 4.

\section{Proof of Lemma 4}

In an economy with a gray market firm, we set $n=0$ and plug the values of $q_{0}^{F}(p), q_{0}^{G D}(p)$, and $q_{g}^{G D}(p)$ from (A4), (A5) and (A7), respectively, into Equation (13). First, (13) is concave in $p$, because $\frac{\partial^{2} S W_{G D}^{p}(p)}{\partial p^{2}}<0$. Differentiating (13) with respect to $p$ yields:

$$
p^{G D S W}(\gamma)=\frac{\alpha_{F}\left(28-13 \gamma^{2}+2 \gamma^{4}\right)-2 \alpha_{D}(2-\gamma)^{2}}{68-35 \gamma^{2}+4 \gamma^{4}}
$$

This transfer price maximizes the social welfare of the domestic economy. This proves Lemma 4.

\section{Proof of Proposition 5}

In an economy with a gray market firm where $n=0$, we set the transfer price that maximizes the multinational's profit from Lemma 2, $p^{G D}(\gamma)$, equal to the transfer price that maximizes domestic social welfare from Lemma $4, p^{G D S W}(\gamma)$. This yields:

$$
\frac{\gamma\left(4 \alpha_{D}+\left(\alpha_{F}-2 \alpha_{D}\right) \gamma\right)}{(2-\gamma)^{2}(2+\gamma)^{2}-\gamma^{2}}=\frac{\alpha_{F}\left(28-13 \gamma^{2}+2 \gamma^{4}\right)-2 \alpha_{D}(2-\gamma)^{2}}{68-35 \gamma^{2}+4 \gamma^{4}}
$$

Rearranging the terms yields the following condition for $p^{G D}(\gamma)=p^{G D S W}(\gamma)$ : 


$$
\alpha_{F}=\frac{2 \alpha_{D}\left(16+18 \gamma-18 \gamma^{2}-4 \gamma^{3}+3 \gamma^{4}\right)}{112-104 \gamma^{2}+27 \gamma^{4}-2 \gamma^{6}}
$$

So for example if the economy has parameter values of $\alpha_{D}=100, \alpha_{F}=64.53$ and $\gamma=.8$, then per (A10), $p^{G D}(\gamma, n)=p^{G D S W}(\gamma)=21.91$.

Next, in an economy with a gray market firm where $n=0$, we set the multinational's arm's length transfer price from Lemma 3, $p^{G D a r m}(\gamma)$, equal to the

transfer price that maximizes domestic social welfare from Lemma $4, p^{G D S W}(\gamma)$. This yields:

$$
\frac{\alpha_{D}(2 \gamma)(2-\gamma)+\alpha_{F}\left((2-\gamma)^{2}(2+\gamma)^{2}+\gamma^{2}\right)}{2(2-\gamma)^{2}(2+\gamma)^{2}-\gamma^{2}}=\frac{\alpha_{F}\left(28-13 \gamma^{2}+2 \gamma^{4}\right)-2 \alpha_{D}(2-\gamma)^{2}}{68-35 \gamma^{2}+4 \gamma^{4}}
$$

Rearranging the terms yields the following condition for $p^{G D a r m}(\gamma)=p^{G D S W}(\gamma)$ :

$$
\alpha_{F}=-\frac{4 \alpha_{D}\left(16+\gamma-9 \gamma^{2}+\gamma^{4}\right)}{3\left(-4+\gamma^{2}\right)^{2}}
$$

$\alpha_{F}$ is negative for all values of $\gamma \in(0,1]$. A negative intercept for either market's inverse demand function is a contradiction, and thus a multinational's arm's length transfer price in a gray market setting can never equal the price that maximizes the welfare of the domestic economy. This proves Proposition 5.

\section{Proof of Proposition 6}

Expanding (18) yields:

$$
\frac{1}{4\left(16-9 \gamma^{2}+\gamma^{4}\right)}\left(-4 \alpha_{D} \alpha_{F}(-2+\gamma) \gamma+\alpha_{F}^{2}\left(-4+\gamma^{2}\right)^{2}-\alpha_{D}^{2} \gamma\left(16-13 \gamma+\gamma^{3}\right)\right)>0
$$

Simplifying this expression yields:

$$
\left(4-\gamma^{2}\right)^{2}+4 \gamma(2-\gamma) \frac{\alpha_{D}}{\alpha_{F}}-\left(\frac{\alpha_{D}}{\alpha_{F}}\right)^{2}\left(16-13 \gamma+\gamma^{3}\right) \gamma>0
$$


Making (A12) an equality and solving for $\frac{\alpha_{D}}{\alpha_{F}}$ yields two real roots. Designate the smaller root as root 1 and the larger as root 2 . We also denote root 2 as $R^{\text {entry }}$ :

$$
\begin{aligned}
& \operatorname{root} 1=\frac{2 \gamma(2-\gamma)-\sqrt{4 \gamma^{2}(2-\gamma)^{2}+\gamma\left(4-\gamma^{2}\right)^{2}\left(16-13 \gamma+\gamma^{3}\right)}}{\gamma\left(16-13 \gamma+\gamma^{3}\right)} \\
& \operatorname{root} 2=\frac{2 \gamma(2-\gamma)+\sqrt{4 \gamma^{2}(2-\gamma)^{2}+\gamma\left(4-\gamma^{2}\right)^{2}\left(16-13 \gamma+\gamma^{3}\right)}}{\gamma\left(16-13 \gamma+\gamma^{3}\right)} \equiv R^{\text {entry }}
\end{aligned}
$$

For all $\gamma \in(0,1], \quad(\mathrm{A} 12)$ is a concave parabola with a maximum at $\frac{\alpha_{D}}{\alpha_{F}}=\frac{2(2-\gamma)}{\left(16-13 \gamma+\gamma^{3}\right)}>0$. Root 1 is negative and strictly less than $\underline{R}$ so any feasible $\frac{\alpha_{D}}{\alpha_{F}}$ is greater than root 1 and thus root 1 cannot bind. However, for sufficiently high values of $\gamma$, (approx $\gamma=0.96$ ), $R^{\text {entry }}<\bar{R}$, so it is possible that $R^{\text {entry }}$ may bind. It is straightforward to show that $\frac{\alpha_{D}}{\alpha_{F}}<R^{\text {entry }}$ satisfies (A12). This proves proposition 6 . 